\title{
Contest Theory and its Applications in Sports
}

\author{
Helmut Dietl ${ }^{\dagger}$, Egon Franck ${ }^{\dagger \dagger}$, Martin Grossmann ${ }^{\dagger \dagger \dagger}$, and Markus Lang ${ }^{\dagger \dagger \dagger}$ \\ Original: November 2011 \\ Revised: March 2011
}

\begin{abstract}
This paper outlines how the theory of contests is applied to professional team sports leagues. In the first part, we present the traditional Tullock contest and explain some basic properties of the equilibrium. We will then extend this static contest to a two-period model in order to analyze dynamic aspects of contests. In the second part, we will present applications of contest theory in sports. In particular, we will show how the Tullock framework is applied to models of team sports leagues. For this purpose, we will first explain the value creation process in team sports leagues and show how club revenues are related to the contest success function. Then, we present some basic modeling issues; for instance, we show how the assumption of flexible vs. fixed talent supply depends on the league under consideration and how it influences the equilibria. Furthermore, we explicate the effect of revenue sharing on competitive balance in the different models. Then we address the relationship between competitive balance and social welfare. Finally, we illustrate why many clubs tend to "overinvest" in playing talent in many team sports leagues.
\end{abstract}

JEL Classification Codes: C72, L83

Keywords: Contest theory, Tullock contest, sports leagues, competitive balance, revenue sharing, social welfare, overinvestment

${ }^{\dagger}$ Institute for Strategy and Business Economics, University of Zurich, Plattenstrasse 14 CH-8032 Zurich, Switzerland, Phone: +41 (0) 4463453 11, Fax: +41 (0) 4463453 01, helmut.dietl@isu.uzh.ch

${ }^{\dagger}$ Institute for Strategy and Business Economics, University of Zurich, Plattenstrasse 14 CH-8032 Zurich, Switzerland, Phone: +41 (0) 4463428 45, Fax: +41 (0) 4463443 48, egon.franck@isu.uzh.ch

${ }^{\dagger \dagger}$ Institute for Strategy and Business Economics, University of Zurich, Plattenstrasse 14 CH-8032 Zurich, Switzerland, Phone: +41 (0) 4463453 11, Fax: +41 (0) 4463453 01, martin.grossmann@isu.uzh.ch

${ }^{\dagger \dagger \dagger}$ Institute for Strategy and Business Economics, University of Zurich, Plattenstrasse 14 CH-8032 Zurich, Switzerland, Phone: +41 (0) 4463453 17, Fax: +41 (0) 4463453 01, markus.lang@isu.uzh.ch 


\section{Introduction}

This paper explains how contest theory is applied to professional team sports leagues. First, we present some peculiarities of the professional team sports industry, which are needed to understand the modeling of a sports league.

The professional team sports industry is characterized by the following major peculiarities: First, a distinction has to be made between economic competition and competition on the pitch. In sports, any team will try to dominate its opponents and maximize its winning percentage. From a league-wide economic point of view, however, the attractiveness of the championship might be increasing in the closeness of the competition (competitive balance). As a consequence, on aggregate, the absence of single teams dominating the championship is economically preferable. This phenomenon is in stark contrast to the notion of economic competition, where the goal of any competitor is to attain monopoly status in order to maximize its profits. Unlike Toyota, Microsoft, and Wal-Mart, who benefit from weak competitors in their respective industries, Real Madrid and the New York Yankees need strong competitors to maximize their revenues. In sports, a weak team produces a negative externality on its stronger competitors.

In sportive competition, scholars such as Rottenberg (1956) and Neale (1964) have recognized early on that an on-pitch monopoly of any single team will lower the team's profits as the championship becomes unattractive and demand subsequently decreases. This is the so-called "uncertainty of outcome" hypothesis. Hence, in order to produce a valuable product, it is necessary for any team to possess potent competitors and a league that coordinates the championship.

Second, any championship race must possess monopoly status per definition. The validity of the championship primarily rests on this monopoly status. If there are several championships per market area and sport, no consistent ranking of all performers is achieved and, hence, the championship will lose a significant part of its value for consumers. A brief look at the history of Major League sports shows that the periods of inter-league competition have been rather short and ended in mergers if the contender succeeded in seriously challenging the established league at all. ${ }^{1}$ In European soccer, this uniqueness of national championships is additionally enforced on a formal basis by UEFA's lack of approval for any national league not licensed by the respective

\footnotetext{
${ }^{1}$ Quirk and Fort (1992) and Fort (2003).
} 
national soccer federation. The definitory monopoly status of Major Leagues yields an important consequence for the participating clubs. Investments of club-owners into their teams are specific in the sense that they cannot be transferred to alternative, equally profitable endeavors. Any individual club-owner has no economically viable exit-option from a monopolistic Major League other than shutting down and selling the team. Therefore, whenever clubs and the league coordinate their relations via contracts, a hold-up risk arises. Having made investments into the teams, club-owners cannot redirect their investments into other businesses without losing a significant part of their value and are thus forced to accept whichever conditions are offered by the league governing body. While European soccer clubs have tried to adapt to this situation by striving to increase their independence from association-governed soccer leagues, the full extent of such a situation is felt in F1 motor racing. Even though no single club-owner can produce a championship race on his own, some subset of clubs may be tempted to threaten to set up some competing league - knowing that the probability of success of such a league might be low a priori. $^{2}$ A standard remedy in the presence of specific investments that helps avoiding unproductive rent seeking is the vertical integration of the two levels of production. The unification of club-owners and the league body under one single corporate roof solves the hold-up problem. Unfortunately, it gives rise to new problems (i.e. integrity, moral hazard) affecting revenue and profits in a detrimental manner. ${ }^{3}$

Third, professional team sports create various satellite markets, which may generate even larger revenues than the primary sports market. A typical example of such a satellite market is the betting market.

Due to its peculiarities and perhaps its popularity, the professional team sports industry enjoys several exemptions from common antitrust regulations. For example, salary caps (Késenne, 2000b; Dietl, Lang, and Rathke, 2009, 2011), transfer restrictions (Dietl, Franck, and Lang, 2008b) and centralized marketing by league monopolies (Falconieri, Palomino, Sakovics, 2004) would not be tolerated in other industries. These exceptions result in very interesting labor market peculiarities within professional team sports. These peculiarities make the industry of professional team sports an interesting research field for economists. Since the industry is

\footnotetext{
2 This is exactly what could - until recently - be observed in F1, where a subset of racing teams threatened not to prolong the "concorde agreement", the agreement governing relations between the team association FOCA and the F1 management, in order to start an own racing league dubbed GPWC.

${ }^{3}$ Dietl, Franck, Hasan and Lang (2009) show how forward integration of clubs into the stage of championship
} 
organized differently across the world and we even can often observe different institutional arrangements within a given country, professional team sports is an interesting source of natural experiments.

The remainder of the paper is organized as follows. In Section 2, we present the traditional Tullock contest and explain some basic properties of the equilibrium. We will then extend this static contest to a two-period model in order to analyze dynamic aspects of contests. In Section 3, we will present applications of contest theory in sports. In particular, we will show how the Tullock framework is applied to models of team sports leagues. The article ends with a short conclusion in Section 4.

\section{A Simple Contest Model}

\subsection{The Basic Tullock Contest}

We consider a contest in which two risk-neutral contestants are competing to win a prize. The contestants differ with respect to the valuation of the prize, where $v_{i}$ denotes contestant $i$ 's valuation of the contest prize. ${ }^{4}$ Each contestant $i=1,2$ independently expends irreversible and costly effort $e_{i} \geq 0$, which will determine via the contest success function (CSF) which contestant will receive the prize. Formally, the CSF maps efforts $\left(e_{1}, e_{2}\right)$ into probabilities of winning the prize for the different contestants. We will only consider the logit formulation, which is probably the most widely used functional form in sporting contests. Its general form was introduced Tullock (1980) and subsequently axiomatized by Skaperdas (1996) and Clark and Riis (1998). ${ }^{5}$ The probability of success for contestant $i=1,2$ in a Tullock contest is defined as

$$
p_{i}\left(e_{1}, e_{2}\right)=\left\{\begin{array}{cc}
\frac{e_{i}^{\gamma}}{e_{1}^{\gamma}+e_{2}^{\gamma}} & \text { if } \max \left\{e_{1}, e_{2}\right\}>0 \\
1 / n & \text { otherwise }
\end{array}\right.
$$

Note that (1) incorporates an adding-up constraint such that the probabilities must sum up to unity, i.e., $p_{1}+p_{2}=1$. The probability of success $p_{i}$ increases in $i$ 's own effort and decreases in

production increases league productivity relative to a contractual interaction of clubs and the league.

${ }^{4}$ See also Nti (1999). Another possibility to model an asymmetric contest is via different marginal costs with respect to effort (see Szymanski and Valletti, 2005) or via different abilities in the CSF (see Dixit, 1987).

${ }^{5}$ For surveys of this CSF in a rent-seeking contest, see Nitzan (1994); Lockard and Tullock (2001). For general properties of this CSF, see Nti (1997). An alternative functional form would be the probit CSF (Lazear and Rosen, 1981; Dixit, 1987) and the difference-form CSF (Hirshleifer, 1989). 
the effort of the other contestants. Moreover, the parameter $\gamma>0$, the so-called "discriminatory power" of the CSF, measures the sensitivity of success to effort. As $\gamma$ increases, the marginal cost of influencing the probability of success decreases, i.e., the probability of winning the contest increases for the contestant with the highest level of efforts, and differences in effort levels affect the winning probability in a stronger way. ${ }^{6}$ For all $\gamma \in(0, \infty)$, the contest under consideration is a so-called "non discriminatory" contest.

In the limiting case where $\gamma$ approaches infinity, we would have a so-called "fully discriminatory" contest where the contestant with the highest effort wins the prize with certainty. ${ }^{7}$ This form of contest is equivalent to an "all-pay auction" in which all bidders must pay regardless of whether they win the prize, which is then awarded to the bidder with the highest bid. ${ }^{8}$ An all-pay auction type of contest is an appropriate approach whenever contestants compete, e.g., in footraces, in which an objective standard like "time" measures success. In contrast, team sports leagues are usually modeled via the "non discriminatory" Tullock contest.

Efforts generate costs according to a cost function $c_{i}\left(e_{i}\right)$, which in the classic contest literature is often assumed to be linear such that ${ }^{9}$

$$
c_{i}\left(e_{i}\right)=c \cdot e_{i},
$$

where $c>0$ is the (constant) marginal cost of efforts.

The expected payoff of contestant $i$ is given by the probability of success $p_{i}$ multiplied by the value of the contest prize $v_{i}$, less the cost of effort:

$$
\pi_{i}=p_{i} v_{i}-c\left(e_{i}\right)=\frac{e_{i}^{\gamma}}{e_{1}^{\gamma}+e_{2}^{\gamma}} v_{i}-c e_{i}
$$

The reaction function of contestant $i$, which describes the best response to any possible effort choice of the other contestant, can be computed from the following FOCs:

${ }^{6}$ Note that $\frac{\partial p_{i}}{\partial \gamma}=\frac{e_{i}^{\gamma}\left(\sum_{j=1, j \neq i}^{n} e_{j}^{\gamma} \ln \left(\frac{e_{i}}{e_{j}}\right)\right)}{\left(\sum_{j=1}^{n} e_{j}^{\gamma}\right)^{2}}>0 \Leftrightarrow e_{i}>e_{j}$ for all $j \neq i$.

${ }^{7}$ For existence conditions of Nash equilibria, see Konrad (2007).

${ }^{8}$ See, e.g., Baye, Kovenock, de Vries (1996). Note that in such a framework with complete information, only Nash equilibria in mixed strategies exist (see, e.g., Dasgupta and Maskin 1986a,b).

${ }^{9}$ Exceptions are Moldovanu and Sela (2001), who analyze the optimal allocation of prizes in an all-pay auction type of contest in which contestants can have linear, concave or convex effort costs. For a dynamic Tullock contest with convex costs, see, e.g., Grossmann and Dietl (2009) and Grossmann, Dietl, Lang (2010). 


$$
\frac{\gamma e_{i}^{\gamma-1} e_{j}^{\gamma}}{\left(e_{1}^{\gamma}+e_{2}^{\gamma}\right)^{2}} v_{i}=c
$$

with $i, j=1,2, i \neq j$. The Nash equilibrium $\left(e_{1}^{*}, e_{2}^{*}\right)$ in pure strategies is then characterized by the intersection of the two reaction functions and is given by

$$
\begin{aligned}
& \left(e_{1}^{*}, e_{2}^{*}\right)=\left(\frac{\gamma v_{1}^{\gamma+1} v_{2}^{\gamma}}{c\left(v_{1}^{\gamma}+v_{2}^{\gamma}\right)^{2}}, \frac{\gamma v_{2}^{\gamma+1} v_{1}^{\gamma}}{c\left(v_{1}^{\gamma}+v_{2}^{\gamma}\right)^{2}}\right), \\
& \left(p_{1}^{*}, p_{2}^{*}\right)=\left(\frac{v_{1}^{\gamma}}{v_{1}^{\gamma}+v_{2}^{\gamma}}, \frac{v_{2}^{\gamma}}{v_{1}^{\gamma}+v_{2}^{\gamma}}\right) .
\end{aligned}
$$

The contestant with the higher valuation of the contest prize expends more effort and wins with a higher probability. Moreover, individual and aggregate efforts are increasing in the valuation of the prize and in the discriminatory power of the CSF. Finally, aggregate effort decreases if the contestants become more heterogeneous with respect to their valuation of the contest prize.

\subsection{Transitional Dynamics in the Tullock Contest}

Contests frequently occur dynamically in several periods because effort decisions are often intertemporarily connected. The effort a contestant exerts in today's contest may affect the probability of winning tomorrow's contest. Examples are numerous: many military conflicts endure for long periods of time, and duopolists compete for customers not only once but every day, much like lobbyists who repeatedly campaign for a political rent. Furthermore, if a political party campaigns for electoral votes, it builds a political reputation that may affect not only this but also subsequent elections.

Grossmann and Dietl (2009) extend the basic model with two contestants by introducing two periods in order to account for these dynamic aspects of contests. ${ }^{10}$ As in Section 2.1, the contestants differ with respect to the valuation of the prize, where $v_{i}$ denotes contestant $i$ 's valuation of the contest prize. Contestant $i=1,2$ contributes effort $e_{i, t}$ in period $t=1,2$. In period 1, contestant $i$ exerts effort $e_{i, 1}$ and builds up an asset stock $E_{i, 1}=e_{i, t}$. The asset stocks $E_{1,1}$ and $E_{2,1}$ determine the probability of success $p_{i, 1}$ of contestant $i$ in period 1 according to 
the Tullock CSF given by (1). ${ }^{11}$ The authors assume that part of the asset stock depreciates according to a depreciation factor $\delta \in(0,1)$. Contestant $i$, however, is able to increase the remaining asset stock by additionally exerting effort $e_{i, 2}$ in period 2. Contestant $i$ 's second-period probability of success $p_{i, 2}$ depends on the resulting asset stocks $E_{1,2}$ and $E_{2,2}$ in period 2. Expected second-period profits are discounted by the factor $\beta \in(0,1)$. In both periods, efforts $e_{i, t}$ generate costs according to a weakly convex cost function given by $c\left(e_{i, t}\right)$ with $c^{\prime}\left(e_{i, t}\right)>0$ for $e_{i, t}>0, c^{\prime}(0)=0$, and $c^{\prime \prime}\left(e_{i, t}\right) \geq 0 . .^{12}$

Contestant $i=1,2$ maximizes expected profits $\pi_{i}$, given by

$$
\pi_{i}=\frac{E_{i, 1}}{E_{1,1}+E_{2,1}} v_{i}-c\left(e_{i 1}\right)+\beta\left(\frac{E_{i, 2}}{E_{1,2}+E_{2,2}} v_{i}-c\left(e_{i, 2}\right)\right),
$$

with $E_{i, 1}=e_{i, 1}$ and $E_{i, 2}=(1-\delta) E_{i, 1}+e_{i, 2}$. In order to solve the maximization problem, one has to think about the information structure in this model. Whether contestants are able to observe the opponent's effort choice after period 1 may influence contestants' optimal strategies. In the economics literature, two different concepts have been elaborated in order to solve this kind of maximization problem. If effort choices are (not) revealed after the first period and before exerting second-period effort, then contestants optimally apply closed-loop (open-loop) strategies. ${ }^{13}$

According to the model, if the contestants apply closed-loop (open-loop) strategies, then the term $\partial E_{i, 2} / \partial E_{j, 1}$ for $i, j=1,2$ and $i \neq j$ can differ from zero (equal zero). Grossmann and Dietl (2009) show that in the case of constant marginal costs $c$, closed-loop and open-loop equilibria coincide. In this case, the optimal asset stocks $E_{i, t}^{*}$ of contestant $i=1,2$ in period $t=1,2$ are given by:

\footnotetext{
${ }^{10}$ In the following, we present a simplified version of the model without revenue sharing.

${ }^{11}$ To simplify matters, the discriminatory power parameter $\gamma$ of the CSF is set to $\gamma=1$.

${ }^{12}$ In the case of linear costs, $c^{\prime}(0)$ is positive.

${ }^{13}$ See Fudenberg and Tirole (1991) for a detailed discussion of open-loop and closed-loop strategies.
} 


$$
\begin{aligned}
& \left(E_{1,1}^{*}, E_{2,1}^{*}\right)=\left(\frac{v_{1}^{2} v_{2}}{c[1-\beta(1-\delta)]\left(v_{1}+v_{2}\right)^{2}}, \frac{v_{1} v_{2}^{2}}{c[1-\beta(1-\delta)]\left(v_{1}+v_{2}\right)^{2}}\right) \\
& \left(E_{1,2}^{*}, E_{2,2}^{*}\right)=\left(\frac{v_{2} v_{1}^{2}}{c\left(v_{1}+v_{2}\right)^{2}}, \frac{v_{1}^{2} v_{2}}{c\left(v_{1}+v_{2}\right)^{2}}\right)
\end{aligned}
$$

In equilibrium, the probability of success is then given by

$$
p_{i, t}^{*}=\frac{v_{i}}{v_{i}+v_{j}} \text { with } i, j=1,2, i \neq j, t=1,2 .
$$

It is easy to see that the contestant with the higher prize valuation contributes more effort and achieves a higher probability of success in each period if marginal costs are constant. In comparison to the basic one-period model, contestants increase their efforts in period 1 because the marginal revenues of effort contribution increase due to the transitional effects on second-period assets. However, the extension of the basic model does not alter effort contributions in period 2 compared to the basic model.

On the other hand, the optimal behavior of the contestants changes considerably by assuming strictly convex costs. In the case of a closed-loop concept, two equilibria are possible. In each period, either the contestant with the lower prize valuation contributes more effort or the contestant with the higher prize valuation contributes more effort.

The latter equilibrium is intuitive because the contestant with the higher prize valuation and therefore (ceteris paribus) higher marginal revenues exerts more effort. The former equilibrium, however, is the counterintuitive outcome and differs from the results in the basic model. In this equilibrium, both contestants assume that the contestant with the lower prize valuation contributes more effort in both periods. Note that marginal revenues depend not only on the prize valuation but also on the effort contribution of both contestants. The contestant with the lower prize valuation anticipates that a higher effort contribution in period 1 decreases the opponent's second-period efforts. ${ }^{14}$ Therefore, marginal revenues increase for the contestant with the lower prize valuation due to this strategic effect. Otherwise, the contestant with the higher prize valuation anticipates that a higher effort contribution in period 1 increases the opponent's second-period efforts. ${ }^{15}$ Thus, marginal revenues decrease for the contestant with the higher prize

\footnotetext{
${ }^{14}$ The contestant's first-period effort is a strategic substitute for the opponent's second-period effort contribution in this equilibrium due to the cross-derivative of the logit CSF.

${ }^{15}$ First-period effort of this contestant is a strategic complement for the opponent's second-period effort contribution in this equilibrium.
} 
valuation. Due to this interaction, it is possible that the contestant with the lower prize valuation exerts more effort in equilibrium.

The extension of the basic model suggests that dynamic aspects may modify contestants' optimal behavior. Moreover, due to the result of multiple equilibria, it is not possible to predict which equilibrium will actually be reached.

In the following sections, we narrow the context of general contests and introduce peculiarities that are typically inherent in sports contests. We show how these peculiarities are embedded in the sports contest models, and we discuss their implications on the optimal behavior of the contestants.

\section{Applications of Contest Theory in Sports}

The research in the application of contest-theoretical concepts to sporting activities is primarily focused on professional team sports to the comparative neglect of individual (non-team) sports such as golf, boxing, athletics, auto sports and the like. ${ }^{16}$ Although individual sports are sometimes organized on a team basis, the teams are not generally organized in leagues ranked in line with their success over the season. The main reason why sports economists are interested in team sports is that "professional team sports leagues are classic, even textbook, examples of business cartels" (Fort and Quirk, 1995).

In this section, we will present applications of contest theory in sports. In particular, we will show how the Tullock framework is applied to models of team sports leagues. For this purpose, we will explain the value creation process in team sports leagues in and show how club revenues are related to the contest success function. Then, we present some basic modeling issues; for instance, we show how the assumption of flexible vs. fixed talent supply depends on the league under consideration and how it influences the equilibria. Furthermore, we explicate the effect of revenue sharing on competitive balance in the different models. Then we address the relationship between competitive balance and social welfare. Finally, we illustrate why many clubs tend to "overinvest" in playing talent in many team sports leagues.

\footnotetext{
${ }^{16}$ Some research has been conducted into individual sports. For instance, see Scully (2000) (athletics); Tenorio (2000) (boxing); Shaw and Jakus (1996) (climbing); Ehrenberg and Bognanno (1990a,b), Orszag (1994) (golf); Fernie and Metcalf (1999) (horse-racing); Maloney and Terkun (2002) (motorcycle-racing); Szymanski (2000) (Olympics); Lynch and Zax (2000), Maloney and Terkun (2000) (running).
} 


\subsection{Value Creation in Team Sports Leagues}

The club-specific revenues of professional sports clubs are largely compiled from five sources: Matchday revenue and broadcasting rights combined account for one-half to three-fourths of total league revenue, the rest is made up by merchandizing, advertising and sponsoring. ${ }^{17}$ At first sight, any single game and the attention generated by it are relevant for matchday and broadcasting revenue. However, when comparing revenues from exhibition games to those from championship games, it becomes evident that the value of the latter significantly exceeds the value of the former. The value of any game depends on the participating teams' playing strengths. But a larger contribution to the game's value is made by the relevance of the game for the championship. Seen from this viewpoint, value-creation in professional team sports occurs on two distinct stages: ${ }^{18}$

On the first stage, the stage of the individual clubs, club-owners invest into the playing strength of their respective teams. No single team, however, is able to produce a marketable product: any team is in need of at least one opponent. The value of the resulting games can then be increased significantly if they are integrated into a championship race. Instead of competing for a contest prize, as in the contest models presented above, in sports leagues, each team has its own revenue generating function which depends on the degree of success of the team and the competitive balance in the league. On the second stage of the production process, the stage of the league, single games act as inputs for the production of the final meta-product, the championship itself. $^{19}$

\subsection{Club Revenues and the Contest Success Function}

In this section, we show how club revenues are related to the contest success function. By concentrating on matchday and broadcasting revenue and by neglecting the other sources of club revenues, Dietl and Lang (2008) and Dietl, Lang, Werner (2009, 2010) derive club-specific revenues from a general fan utility function by assuming that a fan's willingness to pay depends on the fan type, on the preferred team's win percentage, and on the suspense associated with a

\footnotetext{
${ }^{17}$ See Deloitte (2004).

${ }^{18}$ See Franck (2003).

${ }^{19}$ In some leagues such as the European soccer leagues, there exists a third stage, on which the output of the second stage, the national champions, represent inputs for a higher-order championship of national champions, the UEFA Champions League.
} 
close competition (competitive balance). ${ }^{20}$

The authors consider a continuum of fans who differ in their willingness to pay for a match between club $i$ and club $j$ with quality $q_{i} \cdot{ }^{21}$ Every fan $l$ has a certain preference for match quality that is measured by $\theta_{l}$. For simplicity, they assume that these preferences are uniformly distributed in $[0,1]$, i.e., the measure of potential fans is one. Furthermore, they assume a constant marginal utility of quality and define the net utility of $\operatorname{fan} \theta_{l}$ as $\max \left\{\theta_{l} q_{i}-p_{i}, 0\right\}$. At price $p_{i}$, the fan who is indifferent to the consumption of the product is given by $\theta^{*}=\frac{p_{i}}{q_{i}}{ }^{22}$ Hence, the measure of fans who purchase at $p_{i}$ is given by $1-\theta^{*}=\frac{q_{i}-p_{i}}{q_{i}}$. The fan demand function of club $i=1,2$ therefore yields

$$
d\left(m_{i}, p_{i}, q_{i}\right):=m_{i} \frac{q_{i}-p_{i}}{q_{i}}=m_{i}\left(1-\frac{p_{i}}{q_{i}}\right),
$$

where $m_{i} \in \mathrm{R}^{+}$represents the market size parameter of club $i$. Note that fan demand increases in quality, albeit with a decreasing rate, i.e., $\frac{\partial d}{\partial q_{i}}>0$ and $\frac{\partial^{2} d}{\partial q_{i}^{2}}<0$.

Clubs are assumed to be heterogeneous with respect to their market size. For a given set of parameters $\left(p_{i}, q_{i}\right)$, the club with a higher drawing potential ("large-market" club) generates higher demand than the club with lower drawing potential ("small-market" club).

By normalizing all other costs (e.g., stadium and broadcasting costs) to zero, club $i$ 's revenue is simply $R_{i}=p_{i} \cdot d\left(m_{i}, p_{i}, q_{i}\right)$. Then, the club will choose the profit-maximizing price $p_{i}^{*}=\frac{q_{i}}{2}$. Given this profit-maximizing price, club $i$ 's revenue depends solely on the quality of the match and is derived as $R_{i}=\frac{m_{i}}{4} q_{i}$.

The authors further assume that match quality $q_{i}$ depends on two factors: the probability of club $i$ 's success, and the suspense associated with a close competition. The probability of club $i$ 's success is measured by the win percentage of this club, denoted by $w_{i}$.

\footnotetext{
${ }^{20}$ Note that Dietl and Lang (2008) and Dietl, Lang, Werner (2009) implicitly assume that there is decentralized broadcasting such that each club generates its own revenues. For an analysis of centralized versus decentralized broadcasting, see Falconieri, Palomino, Sakovics (2004) and Gurtler (2007).

${ }^{21}$ See also Falconieri, Palomino, Sakovics (2004).

${ }^{22}$ The price $p_{i}$ can, for example, be interpreted as the gate price or the subscription fee for TV coverage of the match.
} 
As standard in the sports economic literature, the relationship between talent investments and win percentage/probability of winning, denoted by $w_{i}$, is characterized by the Tullock CSF (1) presented in Section 2.1:

$$
w_{i}\left(t_{1}, t_{2}\right)=\frac{t_{i}^{\gamma}}{t_{1}^{\gamma}+t_{2}^{\gamma}},
$$

where $t_{i}$ represents the talent investment of club $i .^{23}$

The suspense associated with a close competition is measured by the competitive balance $C B$ in the league and can be specified by the product of the win percentages $w_{i} w_{j} \cdot{ }^{24}$ Competitive balance attains its maximum of $1 / 4$ for a completely balanced league in which both clubs invest the same amount in talent such that $w_{1}=w_{2}=1 / 2$. A less balanced league is then characterized by a lower value of $C B$.

With the specification of the win percentage and competitive balance, the quality function is then derived as

$$
q_{i}=\mu w_{i}+(1-\mu) w_{i} w_{j}
$$

with $i, j=1,2, i \neq j$. The parameter $\mu \in[0,1]$ represents the relative weight that fans put on their own team winning and competitive balance.

The revenue function of club $i=1,2$ is thus given $b^{25}$

$$
R_{i}=\frac{m_{i}}{4} q_{i}=\frac{m_{i}}{4}\left(w_{i}-(1-\mu) w_{i}^{2}\right)
$$

Note that club $i$ 's revenue initially increases with winning until the maximum is reached for $w_{i}=w_{i}^{\prime} \equiv \frac{1}{2(1-\mu)}$. By increasing the win percentage above $w_{i}^{\prime}$, club $i$ 's revenue starts to decrease because excessive dominance by one team is detrimental to match quality. This reflects the uncertainty of outcome hypothesis: the lower the value of $\mu$, i.e., the higher the fans' preference for competitive balance, the lower the threshold value $w_{i}^{\prime}$ and the sooner revenues start to

\footnotetext{
${ }^{23}$ Note that the decision variable in sports contest models is not effort but "playing talent," which is often denoted by $t_{i}$ and is measured in perfectly divisible units.

${ }^{24}$ See also Szymanski (2003) and Vrooman (2008).

${ }^{25}$ This quadratic club-specific revenue function is consistent with the revenue functions used, e.g., in Hoehn and Szymanski (1999); Szymanski (2003); Szymanski and Késenne (2004); Késenne (2006, 2007); Vrooman (2007, 2008).
} 
decrease due to dominance by one team.

If fans only care for their own team winning, i.e. by setting $\mu=1$, the revenue function (3) is linear in $w_{i}$ and is then equivalent to the revenue function derived in the basic Tullock contest. The difference, however, is the interpretation of the parameter $m_{i}$. In the sports context, $m_{i}$ is interpreted as the market size of club $i$, whereas $m_{i}$ is interpreted as the valuation of the contest prize of contestant $i$ in the Tullock contest.

\subsection{Flexible and Fixed Supply of Talent}

In the traditional contest literature, the "supply" of effort $e_{i}$ of contestant $i$ is perfectly elastic and does not influence the supply of the effort of contestant $j$. In contest models of team sports leagues, however, the assumption regarding the supply of talent depends on the league under consideration. In the European sports leagues, talent supply is often assumed to be flexible, especially after the Bosman verdict in 1995, which has established an international player market. In contrast, in the US major leagues, the supply of talent is usually considered as being fixed because all talent wants to play in the major leagues. Under the assumption of a flexible supply of talent, the number of talent hired by club $i$ has no influence on the talent pool that is available to the other club $j$. That is, a club can sign additional talent without decreasing the number of talent in other clubs that compete in the same league. Under the assumption of fixed supply, aggregate talent within the league is constant, and the race for talent is a zero-sum game between owners.

We will see that the assumption regarding the supply of talent crucially affects the modeling of team sports leagues, in particular the derivative of the CSF. By setting the discriminatory power $\gamma$ equal to one, the derivative of the CSF (2) is computed as

$$
\frac{\partial w_{i}}{\partial t_{i}}=\frac{t_{1}+t_{2}-t_{i}\left(1+\frac{d t_{j}}{d t_{i}}\right)}{\left(t_{1}+t_{2}\right)^{2}}
$$

where the term $\frac{d t_{j}}{d t_{i}}$ is called a conjectural variation. The crucial point regarding this conjecture is whether the supply of talent in the league is assumed to be fixed or flexible. As Szymanski (2004) has shown, the assumption of a fixed talent supply is often used to justify the so-called 
"Walrasian fixed-supply" conjecture given by $\frac{d t_{j}}{d t_{i}}=-1$, which means that a one-unit increase in talent hired at team $i$ leads to a one-unit reduction of talent at the other team $j$. In this case, equation (4) yields

$$
\frac{\partial w_{i}}{\partial t_{i}}=\frac{1}{t_{1}+t_{2}} .
$$

In a two-club league, the Walrasian fixed-supply conjecture collapses the non-cooperative choice of talents into a choice of winning percentages by only one club owner. Under the Walrasian fixed-supply conjectures, the game between profit-maximizing owners loses its non-cooperative character and leads to results that are more in line with joint profit-maximization.

In contrast, in a league with a flexible supply of talent, a one-unit increase in talent hired at one team does not influence the amount available to the other team. In such a setting, the so-called Contest-Nash" conjectures are given by $\frac{d t_{j}}{d t_{i}}=0$, leading to

$$
\frac{\partial w_{i}}{\partial t_{i}}=\frac{t_{j}}{\left(t_{1}+t_{2}\right)^{2}} .
$$

Szymanski (2004) argues that the Nash solution to the non-cooperative game of talent choice in a professional sports league $[. .$.$] is inconsistent with the standard representation of the competitive$ equilibrium. According to Szymanski, the so-called Walrasian fixed-supply conjecture model is not meaningful. This model does not fulfill the conditions of a Nash equilibrium, as the incorporation of the constant supply conjectures leaves one team without a choice of strategy. Therefore it makes no sense to talk of any conjectural variation other than zero. Moreover, Szymanski and Késenne (2004) agree with Szymanski (2004), stating that when the choice of one team automatically constrains the other in a two-team model, every possible choice of talent is a Nash equilibrium because the other team has only one feasible response, which is therefore the "best." However, this clearly makes little sense as an economic model.

Fort (2006b), however, has replied to Szymanski's criticism of the Walrasian conjectures and concludes that the appropriate concept depends on the analyzed league. Moreover, Fort and Quirk (2007) show that the competitive talent market model generates a unique rational expectations equilibrium. Thus, the disagreement regarding the Nash conjectures vs. Walrasian 
conjectures still remains an open area for research in the sports economic literature. ${ }^{26}$

We will see in Section 3.4 how assumptions about the supply of talent and the corresponding conjectural variations lead to different results, for example, those regarding the effect of revenue sharing on competitive balance.

\subsection{The Effect of Revenue Sharing on Competitive Balance}

Based on the uncertainty of outcome hypothesis, professional team sports leagues have introduced a variety of measures to increase competitive balance. Two of the most prominent measures are reserve clauses and revenue-sharing arrangements. Whether these measures actually increase competitive balance is the most disputed question in the sports economics literature. According to Rottenberg's "invariance proposition," ${ }^{27}$ the distribution of playing talent between clubs in professional sports leagues does not depend on the allocation of property rights to players' services. In particular, changes in property rights, such as the introduction of a reserve clause, will not alter the allocation of players and will therefore have no impact on competitive balance. El-Hodiri and Quirk (1971), Quirk and El-Hodiri (1974), Fort and Quirk (1995), and Vrooman (1995) extend this invariance proposition to gate revenue sharing.

Traditionally in the sports literature, gate revenue sharing is modeled as follows. The share of revenues that is assigned to the home team is given by the parameter $\alpha \in\left[\frac{1}{2}, 1\right]$, while $(1-\alpha)$ is assumed to be the share of revenues received by the away team. The after-sharing revenues of club $i$, denoted by $R_{i}^{*}$, are then given by

$$
R_{i}^{*}=\alpha R_{i}+(1-\alpha) R_{j}
$$

with $i, j=1,2, i \neq j$ and the revenues $R_{i}$ are given, e.g., by equation (3). Note that a high parameter $\alpha$ represents a league with a low degree of redistribution. That is, $\alpha=1$ characterizes a league without revenue sharing, while $\alpha=1 / 2$ characterizes a league with full-revenue sharing. Another popular form of revenue sharing in sports leagues is pool revenue sharing. Under a pool-sharing arrangement, each club receives an $\alpha$-share of its revenue and an equal $(1-\alpha)$-share of a league revenue pool, where $\alpha \in[0,1]$. In this case, the after-sharing revenues

\footnotetext{
${ }^{26}$ For further discussions, see Eckard (2006) and Szymanski (2006).

${ }^{27}$ Rottenberg's invariance proposition is often regarded as a predecessor of the famous Coase Theorem (see e.g. Fort 2005).
} 
of club $i$ are given by $R_{i}^{*}=\alpha R_{i}+\frac{(1-\alpha)}{2}\left(R_{i}+R_{j}\right)$.

The theoretical analyses regarding the effect of revenue sharing on competitive balance can be grouped along two dimensions of assumptions: profit- versus win-maximization and fixed versus flexible supply of talent. Along the first dimension, club owners may be modeled as either profitor win-maximizers. Profit maximizers do not care about winning percentages unless they affect profits. Win maximizers invest as much as they can into playing talent and are only constrained by zero profit. ${ }^{28}$ The second dimension concerns the elasticity of talent supply as discussed in Section 3.3.

According to this categorization, the invariance proposition with regard to revenue sharing is derived under the assumptions of profit maximization and fixed supply. There is wide agreement that the invariance proposition does not hold in leagues with either win-maximizing owners or a flexible talent supply (see Atkinson, Stanley, Tschirhart 1988; Rascher, 1997; Késenne, 2000, 2005; Vrooman, 2008). There is disagreement, however, over whether the invariance proposition holds in a league with profit-maximizing owners and a fixed talent supply. For example, Szymanski and Késenne (2004) use the usual Nash conjecture and argue that increased gate revenue sharing results in a more uneven distribution of talent between large- and small-market clubs, even in a league with profit-maximizing clubs and a fixed supply of talent.

\subsection{Competitive Balance and Social Welfare}

Even though the relevance of competitive balance for demand is intuitively plausible, there is mixed evidence on its empirical significance. First of all, it is unclear which dimension of competitive balance affects demand the most. Sanderson (2002) as well as Sanderson and Siegfried (2003) differentiate three notions of competitive balance: (i) uncertain match outcome, (ii) uncertain championship outcome and (iii) long-term uncertainty of outcome, that is, the absence of so-called dynasties. Apart of these problems of proxying competitive balance, the empirical evidence on the effects of the different notions of competitive balance onto demand remains ambiguous. Szymanski (2003) surveys 22 empirical studies and concludes that "ten offer clear support for the uncertainty of outcome hypothesis, seven offer weak support, and five

\footnotetext{
${ }^{28}$ For a discussion of the clubs' objective function, see Sloane (1971); Hoehn and Szymanski (1999); Késenne (2000a); Fort and Quirk (2004); Késenne (2006); Garcia-del Barrio and Szymanski (2009).
} 
contradict it". A similar conclusion is drawn by Downward and Dawson (2000), who state that "the evidence suggests that uncertainty of outcome has been an overworked hypothesis in explaining the demand for professional sports". ${ }^{29}$ Note that there is not only mixed empirical evidence on the relevance of competitive balance for attendance but also the specifications used to examine competitive balance and attendance vary significantly across the studies (e.g., the specification of consumer demand and the relevant elements of outcome uncertainty, handling the time series characteristics of attendance data beyond a correction for serial correlation etc.). ${ }^{30}$

In our opinion, the invariance proposition and the related literature on competitive balance miss the point by raising the wrong question. We believe that it is much more important to analyze the welfare effects of different assumptions and issues of league design, such as club owner objectives and revenue sharing, than their effect on competitive balance. If consumers' utility and thus their willingness to pay are increasing in the winning percentage of their supported team, then the clubs' individual potential fan bases, their market sizes, must be considered when deriving the optimal degree of competitive balance. An additional win of a large-market team will generate higher aggregate marginal utility than that of some small-market team, due to the larger number of fans deriving utility from that additional win. Therefore, a fully balanced league might not maximize social welfare because social welfare does not monotonically increase as competitive balance increases. It follows that an exclusive focus on the effects of different assumptions and measures on competitive balance may result in inefficient policy conclusions.

Dietl and Lang (2008) develop a contest model of a team sports league to study the effect of alternative gate revenue-sharing arrangements on social welfare and confirm this finding. By using the usual Nash conjecture, they show that the non-cooperative league equilibrium is too balanced. A lower degree of competitive balance would yield a higher level of social welfare. Moreover, they challenge the invariance proposition by showing that gate revenue-sharing decreases competitive balance. Combining both results, they conclude that in order to increase social welfare, arrangements which decrease, not increase, competitive balance should be

\footnotetext{
${ }^{29}$ See also Borland and MacDonald (2003).

${ }^{30}$ See Fort (2006a) who reviews all of the different ways in which game uncertainty, playoff uncertainty and consecutive season uncertainty have been measured. Moreover, he shows how the specification error of not including all of the different measures of outcome uncertainty can lead to bias in coefficient estimates in demand analyses.
} 
implemented.

In another contest model, Dietl, Lang, Werner (2009) analyze the effects of heterogeneous club objectives on club profits, consumer surplus and player salaries (social welfare). The authors also apply the usual Nash conjecture and show that the social efficiency of measures that increase the competitiveness of small-market clubs depends on the league type. If the large-market clubs are profit-maximizers, for example, small-market clubs should win fewer rather than more games in order to increase social welfare. In such leagues, all measures in favor of small-market clubs, such as transfer restrictions and reverse-order drafts, are dangerous because they will lead to a decrease instead of an increase in social welfare. Moreover, in profit-maximizing leagues, revenue sharing decreases and in win-maximizing leagues it increases competitive balance. In both cases, the effect on social welfare is positive because profit-maximizing leagues have too much and win-maximizing leagues too little competitive balance without revenue sharing. In mixed leagues, on the other hand, revenue-sharing arrangements decrease competitive balance and social welfare.

\subsection{The Overinvestment Problem in Team Sports Leagues}

In this section, we will apply the basic contest model from Section 2.1 to explain the tendency to "overinvest" in playing talent in many team sports leagues.

In the past decade, many football clubs in Europe were able to increase total revenues due to higher broadcasting receipts, bigger crowds, sponsorship and a more professional approach to merchandising. According to Deloitte and Touch (2009), the combined revenues generated by the top divisions of Europe's "Big Five" leagues ${ }^{31}$ increased by more than $300 \%$, from approximately 1.9 billion in the season 1995/96 to 7.7 billion in the season 2007/08. Manchester United, the world's second richest club, even augmented its turnover from 25 million in 1990 to about 325 million in 2008, an increase by $1200 \%{ }^{32}$

At the same time, however, there is growing evidence of a financial crisis spreading throughout the European football leagues. Many European clubs face serious financial difficulties. Some have even gone bankrupt. Examples illustrating this general tendency are

\footnotetext{
${ }^{31}$ The "Big Five" leagues in Europe are: Premier League (England, 20 clubs), Liguel (France, 20 clubs), Bundesliga (Germany, 18 clubs), Primera Division (Spain, 20 clubs) and the Serie A (Italy, 18 clubs).

${ }^{32}$ Economist (2002) and Deloitte and Touch (2009).
} 
numerous: In Spain's Primera Division, the total amount of debt in 2008 amounted to 3.2 billion. Of the top 40 teams, eight sought protection from creditors to stave off bankruptcy in the last two seasons. In particular, FC Valencia is seriously in debt with 502 million. ${ }^{33}$ In England, the 20 Premier League clubs actually owe a total of 2.5 billion in bank overdrafts, loans and other borrowings; Manchester United and Chelsea are the most indebted clubs, each owing about 810 million. ${ }^{34}$ In Italy, the Serie $A$ clubs accumulated total losses of 1.2 billion in the period from $1995 / 96$ up to $2002 / 03$, with $84 \%$ of theses losses sustained from 2000/01-2002/03. ${ }^{35}$ In particular, AC Fiorentina went bankrupt in 2002 and was relegated to the third Italian league. A court declared AC Parma insolvent in April 2004 with 310 million in debt. In Switzerland, Servette Genf was declared insolvent in February 2005; following FC Lugano and Lausanne Sports in 2002, this was the third club to go bankrupt. ${ }^{36}$

How can this "paradox of rising revenues and declining profits" be explained? A first explanation stresses inadequate club constitutions. As organizations without residual claimants, traditional clubs are more likely to behave as win maximizers. Having no ownership stakes in the operation and, at the same time, lacking genuine owners as monitors, club managers have the discretion to maximize individual utility through sportive success. The chance to privatize a part of the fame and glamour derived from sporting success while socializing the inherent financial risks creates strong incentives to invest too much in playing talent. However, a closer look at the real situation in professional team sports shows the limitation of this constitutional explanation. The paradox of raising revenues and declining profits persists even in leagues where clubs have been transformed into capitalistic corporations with profit-maximizing owners. Obviously, the problem must have deeper roots.

Based on a contest model of a team sports league with profit-maximizing clubs, Dietl, Franck, Lang (2008) deal with these roots. They show that the tendency to "overinvest" in playing talent leading to the dissipation of the league's revenue is a direct consequence of the ruinous competition between the clubs. In the following, we will briefly explain their model for a league with two clubs. ${ }^{37}$

\footnotetext{
${ }^{33}$ http://www.football-industry.com

${ }^{34}$ Guardian, 2nd of June 2009.

${ }^{35}$ Deloitte and Touch (2004).

${ }^{36}$ Kicker, 12th of January 2004.

${ }^{37}$ Note that Dietl, Franck, Lang (2008a) consider a league with $n$ clubs. Moreover, they assume a flexible supply of talent and therefore use the "Contest-Nash conjectures".
} 
The authors assume that total league revenue is a concave function of aggregate investments in playing talent, given by ${ }^{38}$

$$
L R\left(t_{1}, t_{2}\right)=\left(t_{1}+t_{2}\right)^{\frac{1}{2}}
$$

This function reflects the fact that with raising investments in playing talent, e.g., better players, the league becomes more attractive for fans or TV broadcasters. Therefore, the league income increases but does so with decreasing returns to scale. The authors consider a league with a revenue sharing arrangement in which the defeated club receives also a certain amount of the league revenue. The share of the endogenously determined league prize $L R\left(t_{1}, t_{2}\right)$ which is awarded to the winner of the championship, is given by the parameter $\alpha \in\left[\frac{1}{2}, 1\right]$, while $(1-\alpha) / 2$ is assumed to be the share of the endogenous league prize received by each of the defeated clubs. Furthermore, in order to concentrate on the overinvestment problem, the authors consider a symmetric league in which both clubs have the same marginal cost of talent investment, i.e., $c_{1}=c_{2}=c$.

The league's optimal level $\left(\bar{t}_{1}, \bar{t}_{2}\right)$ of talent investments maximizes the social surplus of the clubs and is defined as

$$
\left.\bar{t}_{1}, \bar{t}_{2}\right)=\arg \max _{\left(t_{1}, t_{2}\right)}\left(L R\left(t_{1}, t_{2}\right)-c \cdot\left(t_{1}+t_{2}\right)\right) .
$$

By considering the symmetric league optimum only, the solution to the maximization problem is given by $\bar{t}_{i}=\frac{1}{8 c^{2}}$. The terms "overinvest" and "underinvest" are defined as situations in which a club invests more and less, respectively, in equilibrium than in the league optimum.

The expected profit of club $i=1,2$ is given by

$$
\pi_{i}\left(t_{1}, t_{2}\right)=w_{i} \alpha L R\left(t_{1}, t_{2}\right)+\left(1-w_{i}\right)(1-\alpha) L R\left(t_{1}, t_{2}\right)-c t_{i} .
$$

The expected payoff of club $i$ depends on the probability of winning $w_{i}$ multiplied by the share $\alpha$ of the endogenous league prize $L R\left(t_{1}, t_{2}\right)$ awarded to the winner, plus the probability of losing $\left(1-w_{i}\right)$ multiplied by the share $(1-\alpha)$ of the endogenous league prize $L R\left(t_{1}, t_{2}\right)$ awarded to each of the defeated clubs, minus the investment costs in playing talent $c t_{i}$. Note that

\footnotetext{
${ }^{38}$ See also Dietl et al. (2009). In terms of a contest model, the total league revenue can be interpreted as an endogenously-given contest prize (see, e.g., Chung, 1996).
} 
the probability of winning $w_{i}$ is again given by the CSF (2).

Each club chooses an investment level of playing talent such that expected profits (5) are maximized, i.e., club $i$ solves $\max _{t_{i}} \pi_{i}$. The equilibrium investments for club $i=1,2$ are then given by

$$
\begin{aligned}
t_{i}^{*} & =\frac{(1+2 \gamma(2 \alpha-1))^{2}}{32 c^{2}}, w_{i}^{*}=\frac{1}{2}, \\
\pi_{i}^{*} & =\frac{(1+2 \gamma(2 \alpha-1))(3-2 \gamma(2 \alpha-1))}{32 c} .
\end{aligned}
$$

Note that both clubs realize identical, strictly positive investment levels and obtain with an equal probability of $1 / 2$ the endogenously determined league revenue of size $R\left(t_{1}^{*}, t_{2}^{*}\right)=\frac{1+2 \gamma(2 \alpha-1)}{4 c}$. Expected payoffs are non-negative in equilibrium and thus clubs decide to participate in the league competition if either the discriminatory power $\gamma$ is restricted to $\gamma \in[0, \bar{\gamma}(\alpha)]$ with $\bar{\gamma}(\alpha):=\frac{3}{2(2 \alpha-1)}$ or the parameter $\alpha$ is restricted to $\alpha \in\left[\frac{1}{2}, \bar{\alpha}(\gamma)\right]$ with $\bar{\alpha}(\gamma):=\frac{2 \gamma+3}{4 \gamma}$. Otherwise, the competition does not take place because clubs prefer to abstain. ${ }^{39}$

The "ratio of dissipation," which measures the degree of dissipation of the league revenue, is defined as ${ }^{40}$

$$
D(\alpha, \gamma):=\frac{\bar{T}-T^{*}}{\bar{T}}=\frac{(-1+2 \gamma(2 \alpha-1))^{2}}{4} \in[0,1],
$$

where $\bar{T}:=R\left(\bar{t}_{1}, \bar{t}_{2}\right)-c \cdot\left(\bar{t}_{1}+\bar{t}_{2}\right)$ and $T^{*}:=R\left(t_{1}^{*}, t_{2}^{*}\right)-c \cdot\left(t_{1}^{*}+t_{2}^{*}\right)$ characterize the net surplus at the first-best allocation and the Nash equilibrium, respectively. Note that a higher value of $D(\alpha, \gamma)$, implies a higher degree of dissipation of the league revenue.

Dietl, Franck, Lang (2008) show that if (i) the discriminatory power $\gamma$ of the CSF is within the interval $\left(\gamma^{*}, \bar{\gamma}\right]=\left(\frac{1}{2(2 \alpha-1)}, \frac{3}{2(2 \alpha-1)}\right]$, or (ii) the revenue sharing parameter $\alpha$ is within the interval $\left(\alpha^{*}, \bar{\alpha}\right]=\left(\frac{2 \gamma+1}{4 \gamma}, \frac{2 \gamma+3}{4 \gamma}\right]$ there is a guaranteed existence of a Nash equilibrium in which each club invests more than in the league optimum and therefore dissipates parts of the league revenue.

As a consequence, both a higher discriminatory power and a lower degree of revenue sharing

\footnotetext{
${ }^{39}$ Note that comparative statics regarding the equilibrium efforts yield the same results as in standard contest models.

${ }^{40}$ The ratio $D$ is called 'ratio of rent dissipation' in the rent-seeking literature.
} 
contribute to aggravate the "overinvestment" problem in team sports leagues. Intuitively, this is clear; if smaller differences in talent investments have a stronger impact on the probability of success, then the clubs have stronger incentives for higher talent investments. The same holds true for a lower degree of revenue sharing. Moreover, if the discriminatory power or the revenue sharing parameter $\alpha$ equals $\bar{\gamma}(\alpha)$ or $\bar{\alpha}(\gamma)$, then the net surplus $T^{*}$ at the Nash equilibrium equals zero, and $D(\alpha, \gamma)$ reaches its maximum of one. In this case, the clubs dissipate the whole league's revenue. Note that even though marginal costs influence the equilibrium efforts, they have no influence on the "overinvestment" problem because altering marginal costs does not affect the ratio of dissipation. ${ }^{41}$

However, the increase of the talent investments in the Nash-equilibrium compared to the league optimum does not affect the probability of success in equilibrium because clubs simultaneously increase their efforts and end up with exactly the same relative performance as in the league optimum, i.e., $w_{i}^{*}\left(t_{1}^{*}, t_{2}^{*}\right)=w_{i}\left(\bar{t}_{1}, \bar{t}_{2}\right)=1 / 2$. Even though the clubs would be better off if they agreed upon the investment level at the league optimum, this solution does not characterize a feasible equilibrium strategy due to strategic interaction, i.e., it cannot be sustained without cooperation. Starting at the league optimum $\bar{t}_{i}$, club $i$ has an incentive to increase its talent investments because this behavior raises the probability of success to win the share of league revenue awarded to the winner. However, because the other club has the same incentives, both clubs are caught in a typical prisoners' dilemma type of equilibrium. As a result, each club will enter in a ruinous competition leading to the symmetric Nash-equilibrium where the club "overinvests" in talent and achieves no relative gain in performance compared to the league optimum.

\footnotetext{
${ }^{41}$ Note that $D(\alpha, \gamma)$ is independent of marginal costs $c$ because also the league optimum proportionally decreases with $c$.
} 


\section{Conclusion}

Many types of competitions take the form of contests in which competitors make efforts by investing tangible and intangible resources and are rewarded based on their relative efforts. In business, for example, employees compete in promotion contests (Rosen, 1986 and Bognanno, 2001), firms compete in market share contests (Schmalensee, 1976; Piga, 1998), and R\&D labs compete in patent race contests (Loury, 1979, Nalebuff and Stiglitz, 1983; Taylor, 1995). Competition in the form of contests, however, is not limited to the world of business. Contests can be observed in all fields of social life. Litigation (Baye, Kovenock, Casper 2005; Wärneryd, 2000; Gurtler and Krakel, 2008), rent seeking (Nitzan, 1994; Farmer and Pecorino, 1999; Lockard and Tullock, 2001; Baye and Hoppe, 2003), art competitions, beauty pageants, political campaigns (Glazer and Gradstein, 2005; Klumpp and Polborn, 2006), military conflicts (Garfinkel and Skaperdas, 2007), and many other forms of competitions take the form of contests. A further, and perhaps the most obvious, application of contests is sports. Not surprisingly, the contest aspect of sport has attracted considerable attention in the recent sports economics literature (Szymanski, 2003; Szymanski and Késenne, 2004).

This article presented some basic applications of the theory of contest in team sports leagues. After a short outline of the traditional Tullock contest in both a static and a dynamic setting, we explained the relationship between club revenues and the CSF. Then, we analyzed the effect of revenue sharing on competitive balance depending on the assumptions regarding the derivative of the CSF. We further concluded that an exclusive focus on competitive balance may result in inefficient policy conclusions. Finally, the article has shown that, due to the contest structure, team sports leagues carry the risk of "overinvesting" in playing talent. 


\section{References}

Atkinson, S., Stanley, L. and Tschirhart, J. (1988). Revenue sharing as an incentive in an agency problem: An example from the National Football League. The RAND Journal of Economics, 19: $27-43$.

Baye, M. and Hoppe, H. (2003). The strategic equivalence of rent-seeking, innovation, and patent-race games. Games and Economic Behavior, 44: 217-226.

Baye, M., Kovenock, D. and Casper, G. (2005). Comparative analysis of litigation systems: an auction-theoretic approach. Economic Journal, 115: 583-601.

Baye, M., Kovenock, D. and De Vries, C. (1996). The all-pay auction with complete information. Economic Theory, 8: 291-305.

Bognanno, M. (2001). Corporate tournaments. Journal of Labor Economics, 19: 290-315.

Borland, J. and MacDonald, R. (2003). The demand for sports. Oxford Review of Economic Policy, 19: 478-502.

Chung, T. (1996). Rent-seeking contest when the prize increases with aggregate efforts. Public Choice, 87: 55-66.

Clark, D. and Riis, C. (1998). Contest success functions: An extension. Economic Theory, 11: 201-204.

Dasgupta, P. and Maskin, E. (1986a). The existence of equilibrium in discontinous games. Review of Economic Studies, 53: 1-26.

Dasgupta, P. and Maskin, E. (1986b). The existence of equilibrium in discontinuous economic games, I: Theory. The Review of Economic Studies, 53: 1-26.

Deloitte and Touche (2004). Annual review of football finance.

Deloitte and Touche (2009). Annual review of football finance.

Dietl, H., Franck, E., Hasan, T. and Lang, M. (2009). Governance of professional sports leagues - Cooperatives versus contracts. International Review of Law and Economics, 29: 127-137.

Dietl, H., Franck, E., and Lang, M. (2008a). Overinvestment in team sports leagues: A contest theory model. Scottish Journal of Political Economy, 55: 353-368.

Dietl, H., Franck, E., and Lang, M. (2008b). Why football players may benefit from the "shadow of the transfer system." European Journal of Law and Economics, 26: 129-151.

Dietl, H. and Lang, M. (2008). The effect of gate revenue-sharing on social welfare. Contemporary Economic Policy, 26: 448-459. 
Dietl, H., Lang, M., and Rathke, A. (2009). The effect of salary caps in professional team sports on social welfare. The B.E. Journal of Economic Analysis and Policy, 9: Article 17.

Dietl, H., Lang, M., and Rathke, A. (2011). The combined effect of salary restrictions and revenue sharing in sports leagues. Economic Inquiry, 49: 447-463.

Dietl, H., Lang, M., and Werner, S. (2009). Social welfare in sports leagues with profit-maximizing and/or win-maximizing clubs. Southern Economic Journal, 76: 375-396.

Dietl, H., Lang, M., and Werner, S. (2010). The effect of luxury taxes on competitive balance, club profits, and social welfare in sports leagues, International Journal of Sport Finance. 5: 41-51.

Dixit, A. (1987). Strategic behavior in contests. American Economic Review, 77: 891-898.

Downward, P. and Dawson, A. (2000). The Economics of Professional Team Sports. London: Routledge.

Eckard, E. (2006). Comment: "Professional team sports are only a game: The Walrasian fixed-supply conjecture model, contest-Nash equilibrium, and the invariance principle." Journal of Sports Economics, 7: 234-239.

Economist (2002). For love or money. Economist, 363: 7.

Ehrenberg, R. and Bognanno, M. (1990a). Do tournaments have incentive effects? Journal of Political Economy, 13: 1307-1324.

Ehrenberg, R. and Bognanno, M. (1990b). The incentive effect of tournaments revisited: Evidence from the european PGA tour. Industrial and Labor Relations Review, 43: $74 \mathrm{~S}-88 \mathrm{~S}$.

El-Hodiri, M. and Quirk, J. (1971). An economic model of a professional sports league. Journal of Political Economy, 79: 1302-1319.

Falconieri, S., Palomino, F. and Sakovics, J. (2004). Collective versus individual sale of television rights in league sports. Journal of the European Economic Association, 5: 833-862.

Farmer, A. and Pecorino, P. (1999). Legal expenditure as a rent-seeking game. Public Choice, 100: 271-288.

Fernie, S. and Metcalf, D. (1999). It's not what you pay, it's the way that you pay it, and that's what gets results: Jockeys' pay and performance. Labour, 13: 385-411.

Fort, R. (2005). The golden anniversary of 'the baseball players labor market'. Journal of Sports 
Economics, 6: 347-358.

Fort, R. (2006a). Competitive balance in North American professional sports, in J. Fizel, ed., Handbook of Sports Economics Research, ME Sharpe Inc: 190-206.

Fort, R. (2006b). Talent market models in north American and world leagues, in R. Placido, S. Kesenne and J. Garcia, eds, Sports Economics after Fifty Years: Essays in Honour of Simon Rottenberg, Oviedo: Oviedo University Press, 83-106.

Fort, R. and Quirk, J. (1995). Cross-subsidization, incentives, and outcomes in professional team sports leagues. Journal of Economic Literature, 33: 1265-1299.

Fort, R. and Quirk, J. (2004). Owner ob jectives and competitive balance. Journal of Sports Economics, 5: 20-32.

Fort, R. and Quirk, J. (2007). Rational expectations and pro sports leagues. Scottish Journal of Political Economy, 54: 374-387.

Franck, E. (2003). Beyond market power: Efficiency explanations for the basic structures of north American major league organizations. European Sport Management Quarterly, 3: 221-239.

Fudenberg, D. and Tirole, J. (1991). Game Theory. Cambridge, Mass.: MIT Press.

Garcia-del Barrio, P. and Szymanski, S. (2009). Goal! Profit maximization and win maximization in football leagues. Review of Industrial Organization, 34: 45-68.

Garfinkel, M. and Skaperdas, S. (2007). Economics of Conflict: An Overview, in T. Sandler and K. Hartley, eds, Handbook of Defense Economics, Elsevier : 649-709.

Glazer, A. and Gradstein, M. (2005). Elections with contribution-maximizing candidates. Public Choice, 122: 467-482.

Grossmann, M. and Dietl, H. (2009). Investment Behaviour in a Two Period Contest Model. The Journal of Institutional and Theoretical Economics, 165: 401-417.

Grossmann, M., Dietl, H., and Lang, M. (2010). Revenue sharing and competitive balance in a dynamic contest model. Review of Industrial Organization, 36: 17-36.

Gurtler, O. (2007). A rationale for the coexistence of central and decentral marketing in team sports. German Economic Review, 8: 89-106.

Gurtler, O. and Krakel, M. (2008). Double-Sided Moral Hazard, Efficiency Wages, and Litigation. Journal of Law, Economics, and Organization (in press).

Hirshleifer, J. (1989). Conflict and rent-seeking success functions: Ratio vs. difference models of 
relative success. Public Choice, 63: 101-112.

Hoehn, T. and Szymanski, S. (1999). The Americanization of European football. Economic Policy, 14: 204-240.

Késenne, S. (2000a). Revenue sharing and competitive balance in professional team sports.

Journal of Sports Economics, 1: 56-65.

Késenne, S. (2000b). The impact of salary caps in professional team sports. Scottish Journal of Political Economy, 47: 422-430.

Késenne, S. (2005). Revenue sharing and competitive balance - does the invariance proposition hold? Journal of Sports Economics, 6: 98-106.

Késenne, S. (2006). The win maximization model reconsidered: Flexible talent supply and efficiency wages. Journal of Sports Economics, 7: 416-427.

Késenne, S. (2007). The Economic Theory of Professional Team Sports - An Analytical Treatment. Cheltenham, UK: Edward Elgar.

Klumpp, T. and Polborn, M. (2006). Primaries and the New Hampshire effect. Journal of Public Economics, 90: 1073-1114.

Konrad, K. (2007). Strategy in contests-an introduction. WZB-Markets and Politics Working Paper No. SP II 1, 2007.

Lazear, E. and Rosen, S. (1981). Rank-order tournaments as optimum labor contracts. Journal of Political Economy, 89: 841-864.

Lockard, A. and Tullock, G. E. (2001). Efficient Rent-Seeking: Chronicle of an Intel lectual Quagmire. Boston: Kluwer Academic Publisher.

Loury, G. (1979). Market structure and innovation. The Quarterly Journal of Economics, 13: 395-410.

Lynch, J. and Zax, J. (2000). The rewards to running: Prize structure and performance in professional road racing. Journal of Sports Economics, 1: 323-340.

Maloney, M. and Terkun, K. (2000). The response of workers to wages in tournaments: Evidence from foot races. Journal of Sports Economics, 1: 99-123.

Maloney, M. and Terkun, K. (2002). Road warrior booty: Prize structures in motorcycle racing. Contributions to Economic Analysis and Policy, 1: 1-18.

Moldovanu, B. and Sela, A. (2001). The optimal allocation of prizes in contests. American 
Economic Review, 91: 542-558.

Nalebuff, B. and Stiglitz, J. (1983). Prizes and incentives: towards a general theory of compensation and competition. The Bell Journal of Economics, 14: 21-43.

Neale, W. (1964). The peculiar economics of professional sports: A contribution to the theory of the firm in sporting competition and in market competition. Quarterly Journal of Economics, 78: $1-14$.

Nitzan, S. (1994). Modelling rent-seeking contests. European Journal of Political Economy, 10: $41-60$.

Nti, K. (1997). Comparative statics of contests and rent-seeking games. International Economic Review, 38: 43-59.

Nti, K. (1999). Rent-seeking with asymmetric valuations. Public Choice, 98: 415-430.

Orszag, J. (1994): A new look at incentive effects and tournaments. Economics Letters, 46: $77-88$.

Piga, C. (1998). A dynamic model of advertising and product differentiation. Review of Industrial Organization, 13: 509-522.

Quirk, J. and El-Hodiri, M. (1974). The economic theory of a professional sports league, in R. G. Noll, ed., Government and the Sports Business, Washington D.C.: Brooking Institution: $33-80$.

Rascher, D. (1997). A model of a professional sports league, in W. Hendricks, ed., Advances in Economics of Sport, Vol. 2, Greenwich: JAI Press: 27-76.

Rosen, S. (1986). Prizes and incentives in elimination tournaments. American Economic Review, 76: $701-715$.

Rottenberg, S. (1956). The baseball players' labor market'. Journal of Political Economy, 64: $242-258$.

Sanderson, A. (2002). The many dimensions of competitive balance. Journal of Sports Economics, 3: 204- 228.

Sanderson, A. and Siegfried, J. (2003). Thinking about competitive balance. Journal of Sports Economics, 4: 255.

Schmalensee, R. (1976). A model of promotional competition in oligopoly. The Review of Economic Studies, 43: 493-507.

Scully, G. (2000). Diminishing returns and the limit of athletic performance. Scottish Journal of 
Political Economy, 47: 456-470.

Shaw, W. and Jakus, P. (1996). Travel cost models of the demand for rock climbing. Agricultural and Resource Economics Review, 25: 133-142.

Skaperdas, S. (1996). Contest success functions. Economic Theory, 7: 283-290.

Sloane, P. (1971). The economics of professional football: The football club as a utility maximizer. Scottish Journal of Political Economy, 17: 121-146.

Szymanski, S. (2000). The market for olympic gold medals. World Economics, 1: 1-8.

Szymanski, S. (2003). The economic design of sporting contests. Journal of Economic Literature, 41: 1137-1187.

Szymanski, S. (2004). Professional team sports are only a game: The Walrasian fixed supply conjecture model, contest-Nash equilibrium and the invariance principle. Journal of Sports Economics, 5: 111-126.

Szymanski, S. (2006). Reply: "Professional team sports are only a game: The Walrasian fixed-supply conjecture model, contest-Nash equilibrium, and the invariance principle." Journal of Sports Economics, 7: 240-243.

Szymanski, S. and Késenne, S. (2004). Competitive balance and gate revenue sharing in team sports. The Journal of Industrial Economics, 52: 165-177.

Szymanski, S. and Valletti, T. (2005). Incentive effects of second prizes. European Journal of Political Economy, 21: 467-481.

Taylor, C. (1995). Digging for golden carrots: an analysis of research tournaments. American Economic Review, 85: 872-890.

Tenorio, R. (2000). The economics of professional boxing contracts. Journal of Sports Economics, 1: 363-384.

Tullock, G. (1980). Efficient rent-seeking, in J. Buchanan, R. Tollison and G. Tullock, eds, Toward a Theory of Rent Seeking Society. Texas: University Press: 97-112.

Vrooman, J. (1995). A general theory of professional sports leagues. Southern Economic Journal, 61: 971-990.

Vrooman, J. (2007). Theory of the beautiful game: The unification of European football. Scottish Journal of Political Economy, 54: 314-354.

Vrooman, J. (2008). Theory of the perfect game: Competitive balance in monopoly sports leagues. Review of Industrial Organization, 31: 1-30. 
Wärneryd, K. (2000). In defense of lawyers: moral hazard as an aid to cooperation. Games and Economic Behavior, 33: 145-158. 